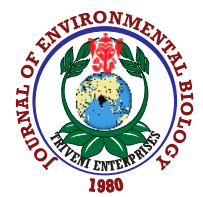

\title{
Survey of bee friendly flowering plants and bee-plant interaction in an urban green space in Bengaluru, India
}

\author{
V.R. Bhatta and A.N. Kumar ${ }^{2 *}$ \\ 'Departments of Zoology and Genetics, Jyoti Nivas College Autonomous, Bengaluru-560 095, India \\ 'Department of Zoology, Periyar University, Salem-636 011, India \\ *Corresponding Author Email : naresh.phd@gmail.com
}

\section{Abstract}

Aim: To study bee friendly plant species, nutritional sources, flowering season, and the dynamic relationship between urban flora and native bee species in a centrally located urban green space in Bengaluru, India.

Methodology: Flowers of different plant species visited by bees were observed and recorded from September 2018 to August 2019. Based on the foraging pattern of visiting bees, the plants were classified into nectar or pollen or both nectar and pollen species. The monthly abundance of nutritional resources was estimated based on the floral phenology.

Results: A total of 51 plant species, from 25 families, were visited by bees for foraging. Polylectic social bees namely Apis florea and Tetragonula iridipennis, visited 45 and 39 plant species, and two species of solitary
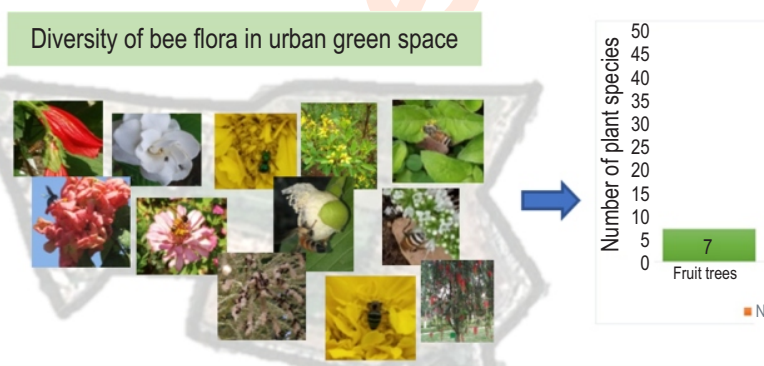

51 species of plants, from 25 families, were visited by the diverse community of bees. Landscape was dominated by ornamental plants and also included vegetables, fruit trees, spontaneous wild vegetation. Plant species with nectar and pollen resources were predominant over only nectar or pollen species. $72 \%$ of the floral species bloomed all the year round, ensuring continuous nutritional supply throughout the year.

Protection and restoration of bee friendly urban green spaces can promote bee diversity and create a balance between urban development and conservation.

bees, namely Amigella cingulate and Xylocopa violacea, visited 26 and 23 plant species, respectively. The urban green landscape was dominated by a variety of ornamental plants (49\%) and also included vegetables (17.6\%), fruit trees (13.7\%), and weeds (19.6\%). Plants that served as a source of both nectar and pollen (60.8\%) were predominant over those that supplied either nectar alone (24.5\%) or pollen alone (13.7\%). Moreover, $72 \%$ of the species bloomed all the year round, which meant that floral resources were available to bees throughout the year.

Interpretation: The study underscores the role of bee friendly floral diversity in the urban green spaces in protection and conservation of bee diversity. Efficient management of urban green spaces can provide dynamic habitat for bee conservation and can prevent the loss of biodiversity.

Key words: Bee diversity, Floral resources, Green spaces, Nectar sources, Pollens 


\section{Introduction}

Bees are important pollinators of both cultivated and wild plants (Potts et al., 2016; Todd et al., 2016), and yet the global bee population and their diversity have seen an alarming and unprecedented decline (Biesmeijer et al., 2006; Kerr et al., 2015). Declining pollinator diversity can pose a serious threat to the stability of the agricultural and natural ecosystems (Gallai et al., 2009). The loss or degradation of habitats, more intensive farming (Tilman et al., 2001), increasing urbanization, changes in land cover (Carvell et al., 2006; Roulston et al., 2011), and lack of nectar and pollen sources are considered major threats to bee diversity (Klein et al., 2007; Stoate et al., 2009). However, despite the loss of natural habitat and the associated decline of pollinators (Hinners and Hjelmroos-Koski, 2009; Pardee and Philpott, 2014), recent studies report larger populations of bees in cities (Threlfall et al., 2015; Daniels et al., 2020; Bhatta and Kumar, 2020).

The greater plant diversity found in semi-natural habitats favours bee communities mainly because of increased heterogeneity of nectar and pollen resources (Potts et al., 2003; Ebeling et al., 2008). Similarly, the heterogeneity of flora in urban green spaces ensures the nutritional stability, therefore, increase bee diversity in urban ecosystems and thus contribute to the conservation of bee diversity and also plants pollinated by them. Urban greening has assumed greater importance in sustainable urban development and urban biodiversity conservation (Baldock et al., 2015; Hall et al., 2017). Anthropogenically altered localized patches of green cover in cities with a mosaic of diverse floral species (Frankie et al. 2005; Matteson et al., 2008; Aguirre-Gutierrez et al., 2015) have become isolated green pastures supporting biodiversity (Frund et al., 2010; Bates et al., 2011; Bhatta and Kumar, 2020). Restoration and conservation of existing green spaces offer a promising opportunity to preserve bee population and can compensate for the loss of bee diversity occasioned by drastic changes in land cover. Although the increase in bee diversity in urban green spaces is well documented, comprehensive data are lacking on the characters of such habitats relevant to bee diversity. As flowers are the only source of nutrition for bees, the diversity, quality, and composition of flowering plants within human-dominated urban habitats play an important role in shaping bee population (Filipiak, 2018) and also for their longterm conservation (Rosenzweig, 2003).

Bees exploit a range of plant species for nutrition, and effective management of bee population requires detailed knowledge of pollinator-friendly plant species, flowering periodicity, flowering duration (Petanidou et al., 2014; Wubie et al., 2014), and spatio-temporal availability of nutritional resources (Reidinger et al., 2014). India being an agrarian country, studies on bee diversity are restricted to farm productivity and those on bee flora, to commercial beekeeping: the importance of such studies to ecology, especially to urban ecology, is seldom realized and data on bee diversity and flora for bees in cities are therefore sparse. Comprehensive data of bee-friendly plant diversity in city landscapes can thus help in restoration and conservation of threatened urban biodiversity. Such sustainable approach for conservation is more important in a fast-developing country such as India undergoing rapid urbanization and a third of its population living in cities. Bengaluru, nicknamed the Garden City and India's second fastest-growing and fifth largest city, has seen unprecedented expansion. Restoration and maintenance of plants that are potential foraging resources for bees can provide a sustainable environment for bees in the fragmented urban habitats. Efficient management of green landscapes in the city can therefore counteract the loss of biodiversity. In view of the above, the present study was carried out to assess the suitability and sustainability of urban green spaces for native bees by undertaking a systematic and comprehensive survey of beefriendly species of flowering plants and floral phenology in a pocket of open green space in Bengaluru.

\section{Materials and Methods}

Study area: The site selected for the study was an urban green space housing government offices and staff quarters spread over 20 ha in the heart of Bengaluru. The vegetation consisted of trees, shrubs, and grasses. The average monthly temperature ranged from $19.4^{\circ} \mathrm{C}$ to $30.0^{\circ} \mathrm{C}$ and the average monthly relative humidity from $45 \%$ to $79 \%$. The mean annual rainfall is $859 \mathrm{~mm}$. Three transects measuring $100 \mathrm{~m} \times 25 \mathrm{~m}$ with diverse flora in an inhabited part of the study area was selected for sampling the flora and bee diversity (Westphal et al., 2008).

Identification of floral resources: Flowers of different plant species visited by the bees were observed and recorded in the morning hours, between 06:30 and 11:30, twice a month from September 2018 to August 2019. A plant was considered a beeforaging species if at least three bees (irrespective of species) visited its flowers within a span of 5 min during the observation hours (Wyaker and Baviskar, 2015). Each visit was considered as pseudo replicate. The more common native plant species were identified in the field, and those that could not be identified in-situ were identified by taxonomist by examining the vegetative and floral parts. The recorded species of flowering plants were categorized as vegetables, fruits, ornamentals, or weeds (spontaneous vegetation).

Based on the foraging habits of bees, the identified plant species were also grouped into nectar, pollen or both nectar and pollen yielders, based on the foraging habits of the bees (Bista and Shivakoti, 2001). Flowers were considered as a source of nectar $(\mathrm{N})$ if bees extended their proboscis into the flowers and as a source of pollen $(P)$ if bees carried pollen on their hind legs. The combined activity of extending their proboscis into the flowers and collecting pollen on their hind legs marked the plant as a source of both nectar and pollen $(N+P)$.

Monthly abundance of bee flora: The percentage monthly abundance of flora was estimated to understand the periodicity of available floral resources (Pande and Ramkrushna, 2018). 
Monthly abundance of bee flora is the percentage of plant species that was available each month in the study area.

\section{Results and Discussion}

The urban habitat selected for the study consisted of a diverse vegetation mix of ornamentals, fruits, vegetables, and weeds. A total of 51 botanical species suitable for foraging by bees were recorded, representing 25 families (Table 1), the dominant among them being Fabaceae, with six species (12\%), followed by Rubiaceae (five species, 10\%) and Malpighiaceae (four species, 8\%) (Table1). The overall flora was dominated by 25 species of ornamental plants, followed by 10 of spontaneous vegetation, 9 of vegetables, and 7 of fruits (Tables 2 and 3). Previous studies on floral diversity have documented the flora in natural, agricultural and semi-urban habitats across India. For instance Waykar et al. (2014) a study conducted in the hilly areas of the Western Ghats, a mountain range that runs north-south and roughly parallel to India's western coast, reported 52 species of flowering plants comprising 29 cultivated species and 23 wild species but recorded no ornamental plant species. Hosamani et al. (2018), from their work in a natural habitat in Kopppal district of Karnataka, reported 84 species dominated by medicinal plants, vegetables, and fruit species: ornamental species were the smallest category, with only nine members.

Table 1: Major botanical families of bee friendly plant species and their distribution in the studied urban green space during the study period

\begin{tabular}{lll}
\hline Family & No. of species & Share (\%) \\
\hline Fabaceae & 6 & 12 \\
Rubiacece & 5 & 10 \\
Malpighiaceae & 4 & 8 \\
Solanaceae & 3 & 6 \\
Amaranthaceae & 3 & 6 \\
Myrtaceae & 3 & 6 \\
Asteraceae & 3 & 6 \\
Arecaceae & 3 & 6 \\
Lamiaceae & 2 & 4 \\
Malvaceae & 2 & 4 \\
Lythraceae & 2 & 4 \\
Oxalidaceae & 2 & 4 \\
Poaceae & 2 & 2 \\
Rutaceae & 1 & 2 \\
Brassicaceae & 1 & 2 \\
Apiaceae & 1 & 2 \\
Moringaceae & 1 & 2 \\
Sapotaceae & 1 & 2 \\
Caesalpiniaceae & 1 & 2 \\
Bignoniaceae & 1 & 2 \\
Rosaceae & 1 & 2 \\
Apocynaceae & 1 & 2 \\
Muntingiaceae & 1 & 2 \\
Euphorbiaceae & 1 & 2 \\
Commelinaceae & 3 & 2 \\
\hline
\end{tabular}

In an another survey in Wardha district of Maharashtra, Pande and Ramkrushna (2018) documented 92 species dominated by cultivated species (50) and wild species (30) but only 12 species of ornamental plants. Mahale (2019) recorded 54 species of wild plants and weeds from farmlands and forests in Gujarat. Although the urban green space was similarly diverse in terms of its flora, its composition was very different: human interference, the inevitable feature of any urban landscape, favours ornamental plants and suppresses spontaneous wild vegetation-an intervention that not only enhanced the aesthetic value of the habitat but also provided more diverse floral resources for the native bees. These findings confirm that despite human interference, urban green spaces with unique assemblage of floral species dominated by ornamentals can serve as potential habitats for bees. The nutritional value of a plant to bees depends on the content of pollen and nectar in its flowers (Keller et al., 2005). The quantity and composition of nectar is an important species-specific trait for food selection in bees (Chalcoff et al., 2017). Pollen being the main source of protein is mainly responsible for the growth and reproduction of bees and the nutritional value of pollen resources greatly influence the pattern of pollen collection (Roulston et al., 2000). In the present study, plants that supplied both nectar and pollen were the most abundant $(60.8 \%)$, followed by those that supplied only nectar $(24.5 \%)$ and only pollen (13.7\%). Out of 25 ornamental species, 15 species supplied nectar and pollen, 8 supplied only nectar and 2 supplied only pollen, indicating the dominance of ornamental flora and predominance of both nectar and pollen sources. Of the nine vegetable species, five species supplied both and four supplied only pollen, whereas all the fruit and weed species supplied both.

Among the diverse flora, the ornamentals were predominant nutritional resource in the study area. Hemalatha et al. (2018) and Vidya et al. (2019) have also reported the predominance of species that supply both nectar and pollen in agricultural, horticultural, and natural habitats in Madurai city of Tamil Nadu. This confirmed that despite variation in the composition of floral species, urban habitats are similar to agricultural, horticultural or natural habitats in terms of foraging resources for bees. The plants in the urban habitat varied in their blossoming season: round-the-year flowering species were predominant $(63.3 \%)$ over seasonal flowering species (36.7\%). All the weed species bloomed throughout the year, similar to 16 ornamentals, 4 vegetables, and 2 fruit trees. Abundance of annual flowering species are of great significance in the urban habitat as they confirm the continuous availability of floral resources supporting the diverse bee species in urban habitats. Monthly floral abundance ranged from $72.5 \%$ in January, October, and December to $88.2 \%$ in March, April and May (Fig.1), which was also the period of maximum flow of honey. Species that flowered during March to May included mass flowering trees as Callistemon citrinus, Samanea saman, Cassia fistula, Delonix regia, Pongamia pinnata and Peltophorum pterocarpum (Table 2), thus ensuring abundant nutritional resources in the study area. 
Table 2: Diversity of ornamental and wild plant species, their flowering period and the type of nutritional sources collected by the foraging bee species in urban green space

\begin{tabular}{|c|c|c|c|}
\hline Scientific names & Family & Flowering period & Nutritional source \\
\hline Tecoma capsensis & Bignoniaceae & Jan-Dec. & $\mathrm{N}$ \\
\hline Malvaviscus penduliforus & Malvaceae & Jan-Dec & $\mathrm{N}$ \\
\hline Rosa centifolia & Rosaceae & Jan-Dec & $P$ \\
\hline Lagerstroemia indica & Lythraceae & Apr-Jun & $\mathrm{N}+\mathrm{P}$ \\
\hline Lagerstroemia speciosa & Lythraceae & Apr-Jun & $\mathrm{N}+\mathrm{P}$ \\
\hline Gardenia jasminoides & Rubiaceae & Jan-Dec & $\mathrm{N}$ \\
\hline Ixora arborea & Rubiaceae & Jan-Dec & $\mathrm{N}$ \\
\hline Galphimia gracilis & Malpighiaceae & Jan-Dec & $\mathrm{P}$ \\
\hline Mussaenda philippica & Rubiaceae & Jan-Dec & $\mathrm{N}$ \\
\hline Hamelia patens & Rubiaceae & Jan-Dec & $\mathrm{N}$ \\
\hline Tagetes erecta & Asteraceae & Jan-Dec & $N+P$ \\
\hline Zinnia elegans & Asteraceae & Nov.-Aug. & $\mathrm{N}+\mathrm{P}$ \\
\hline Tagetes tenuifolia & Asteraceae & Jan-Dec & $\mathrm{N}+\mathrm{P}$ \\
\hline Callistemon citrinus & Myrtaceae & June-Nov, Feb.-May & $\mathrm{N}$ \\
\hline Samanea saman & Fabaceae & Sept.-Dec, Mar.-May & $\mathrm{N}$ \\
\hline Cassia fistula & Fabaceae & Feb-May & $\mathrm{N}+\mathrm{P}$ \\
\hline Delonix regia & Fabaceae & Mar-May & $N+P$ \\
\hline Pongamia pinnata & Fabaceae & Mar-May & $N+P$ \\
\hline Peltophorum pterocarpum & Fabaceae & Mar-May & $N+P$ \\
\hline Nerium Oleander & Apocynaceae & Jan-Dec & $\mathrm{N}$ \\
\hline Muntingia calabura & Muntingiaceae & Jan-Dec & $\mathrm{N}+\mathrm{P}$ \\
\hline Roystonea regia & Arecaceae & Jan-Dec & $N+P$ \\
\hline Dypsis lutescens & Arecaceae & Jan-Dec & $\mathrm{N}+\mathrm{P}$ \\
\hline Ocimum sanctum & Lamiaceae & Jan-Dec & $\mathrm{N}+\mathrm{P}$ \\
\hline Cassia alexandrina & Fabaceae & Jan-Dec & $\mathrm{N}+\mathrm{P}$ \\
\hline \multicolumn{4}{|c|}{ Weeds (spontaneous vegetation) } \\
\hline Oxalis dillenii & Oxalidaceae & Jan-Dec & $\mathrm{N}$ \\
\hline Oxalis corymbosa & Oxalidaceae & Jan-Dec & $\mathrm{N}$ \\
\hline Alternanthera paronychioides & Amaranthaceae & Jan-Dec & $\mathrm{N}$ \\
\hline Alternanthera sessilis & Amaranthaceae & Jan-Dec & $N+P$ \\
\hline Mitracarpus hirtus & Rubiaceae & Jan-Dec & $\mathrm{N}+\mathrm{P}$ \\
\hline Euphorbia hirta & Euphorbiaceae & Jan-Dec & $P$ \\
\hline Calyptocarpus vialis & Asteraceae & Jan-Dec & $\mathrm{N}$ \\
\hline Cyanotis cristata & Commelinaceae & Jan-Dec & $N+P$ \\
\hline Cynodon dactylon & Poaceae & Jan-Dec & $N+P$ \\
\hline Eremochloa ophiuroides & Poaceae & Jan-Dec & $N+P$ \\
\hline
\end{tabular}

${ }^{*} \mathrm{~N}+\mathrm{P}=$ Nectar and pollen source; $\mathrm{P}=$ Only pollen source; $\mathrm{N}=$ Only nectar source

These results are consistent with reports of maximum honey flow being in April and May in natural habitats in Maharashtra, which coincides with peak flowering of wild plants (Bista and Shivakoti, 2001; Pande and Ramkrushna, 2018). In contrast, April and May are lean months in agricultural habitats, October to December being the period with abundant flowers (Waykar and Baviskar, 2015; Hosamani et al., 2018). Therefore, urban green spaces can sustain bee diversity by offering continuous supply of floral resources round the year and are in fact better than agricultural habitats, in which foraging resources are scarce in some months (Waykar and Baviskar, 2015).

The flora of the landscape and their floral resources, mainly the quality and quantity of pollen and nectar greatly influence the bee diversity and population (Woodard and Jha, 2017). Earlier study (Bhatta and Kumar, 2020) has documented 19 species of native bees in the study area, belonging to 16 genera under 3 families, namely Apidae, Halictidae, and Megachilidae in the urban green area. Bee diversity was strongly correlated to the floral resources of the habitat. The recorded bee species were generalists and oligolectic in that they foraged a wide variety of flowers. Apis florea was the most adapted species: it visited 41 flowering plant species in the study area; Tetragonula iridipennis visited 39 and Apis dorsata, 36 . Among the solitary bees, Amigella cingulata was recorded on 30 species and Xylocopa violacea, on 23 (Fig. 2). Similar results were reported from a natural habitat in Aurangabad district of Maharashtra: the study recorded 22 species of native 
Table 3: Diversity of vegetables and fruit trees with flowering period and the type of nutritional sources collected by the foraging bees in the study area

\begin{tabular}{|c|c|c|c|}
\hline Scientific names & Family & Flowering period & Nutritional source \\
\hline \multicolumn{4}{|c|}{ Vegetables } \\
\hline Solanum melongena & Solanaceae & Jun-Nov & $P$ \\
\hline Amaranthus retroflexus & Amaranthaceae & Mar-Jul, Sep-Nov & $P$ \\
\hline Solanum lycopersicm & Solanaceae & Jan-Dec & $\mathrm{P}$ \\
\hline Capsicum annuum & Solanaceae & Jan-Dec & $N+P$ \\
\hline Brassica juncea & Brassicaceae & May-Sep & $N+P$ \\
\hline Coriandrum sativum & Apiaceae & Jan-Dec & $N+P$ \\
\hline Mentha spicata & Lamiaceae & Jun-Aug, Mar-May & $\mathrm{N}+\mathrm{P}$ \\
\hline Abelmoschus esculentus & Malvaceae & Jan-Dec & $P$ \\
\hline Moringa oleifera & Moringaceae & Nov-Mar & $\mathrm{N}+\mathrm{P}$ \\
\hline \multicolumn{4}{|c|}{ Fruits } \\
\hline Citrus limon & Rutaceae & Nov-Feb, Jun-Sep & $\mathrm{N}+\mathrm{P}$ \\
\hline Psidium guajava & Myrtaceae & Jan-Mar, Jun-Sep & $N+P$ \\
\hline Manilkara zapota & Sapotaceae & Sept-Jan & $N+P$ \\
\hline Musa paradiscica & Musaceae & Jan-Dec & $\mathrm{N}+\mathrm{P}$ \\
\hline Syzygium malaccense & Myrtaceae & Mar-May & $N+P$ \\
\hline Tamarindus indica & Fabaceae & Mar-May & $N+P$ \\
\hline Cocus nucifera & Arecaceae & Jan-Dec & $\mathrm{N}+\mathrm{P}$ \\
\hline
\end{tabular}

${ }^{*} \mathrm{~N}+\mathrm{P}=$ Nectar and pollen source; $\mathrm{P}=$ Only pollen source; $\mathrm{N}=$ Only nectar source

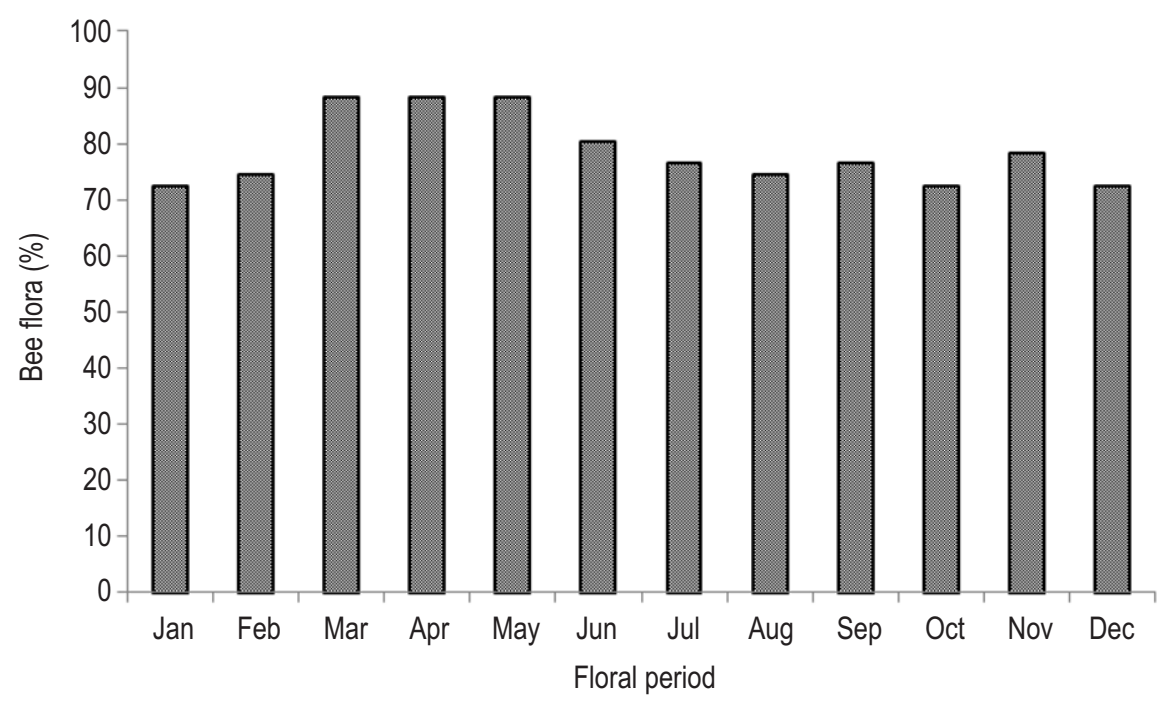

Fig.1: Monthly percentage of bee friendly plant species and the floral phenology in the urban green space during the study period.

bees from the same three families, namely Apidae, Megachilidae, and Halictidae (Balachandra and Baviskar, 2015), with Apidae being the predominant family and Apis florea as the most common and widely distributed species. Although changes in landscape were reported to affect bee diversity adversely (Weiner et al., 2014), the present study clearly shows the positive effects of diversity in floral composition on bee diversity in urban areas. To our knowledge, no data are available on the bee friendly floral diversity of Indian urban green spaces: we presume the present study to be the first of its kind in the country. The plant species that served as major nutritional resources for bees were Moringa oleifera, Solanum lycopersicum, Mentha spicata, Coriandrum sativum, Cocus nucifera, Tamarindus indica, Cassia alexandrina, Capsicum annuum and Solanum melongena among species that yield edible products. Callistemon citrinus, Samanea saman, Syzygium malaccense, Ocimum sanctum, Galphimia gracilis, Targetes ereta, Zinnia elegans, Dypsis lutescens, Roystonea regia, Muntingia calabura and Cassia fistula were the major ornamental species. Additionally, some wild plants and lawn 


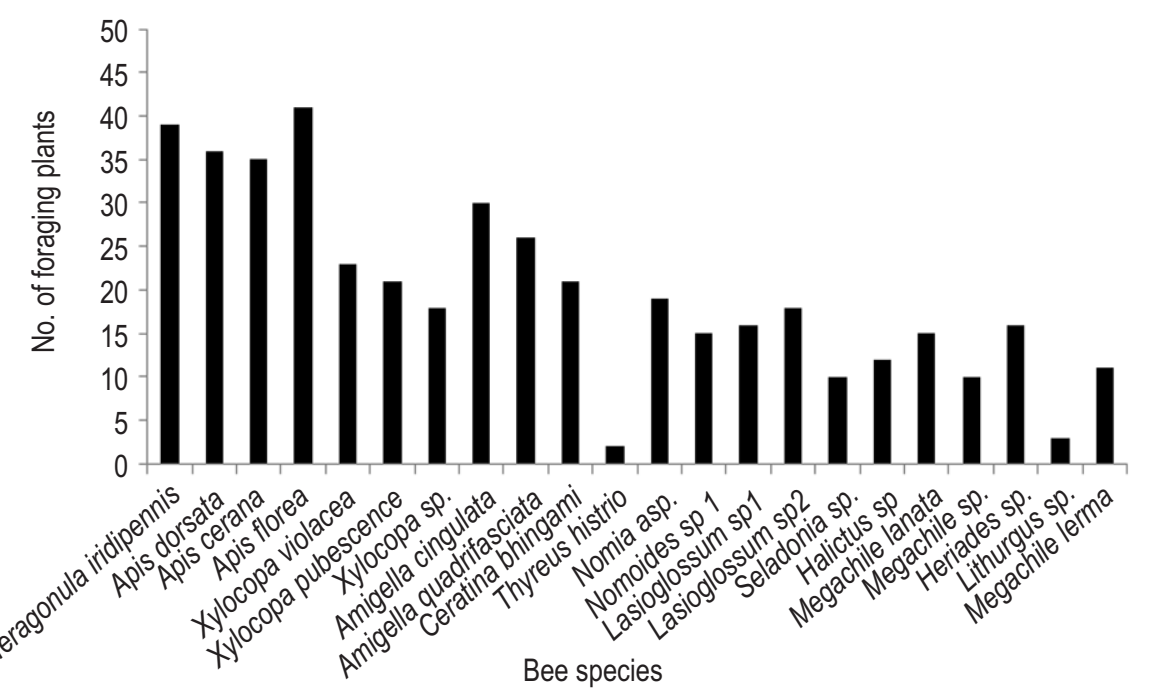

Fig.2: Total number of plant species visited by different bee species in the studied urban green space during the survey period.

grasses from open areas also supported diverse bee taxa in the study area. The two ornamental species from Arecaceae, namely Dypsis lutescens and Roystonea regia, offered rich resources to social bees. A sacred species, namely Ocimum sanctum, and ornamental species, Targetes ereta and Zinnia elegans supported several species of solitary bees round the year. Similar study conducted (Vidhya et al., 2019) in the horticultural ecosystem in Madurai district in Tamil Nadu has also reported 45 plant species from 26 families as major foraging sources for Apis florea. Plant species such as Pongamia, Syzygium, Lagerstroemia, Citrus, Cocos, etc. were reported as the major genera, as they were in the urban habitat chosen for the present study. This shows that, despite land management changes and anthropogenic interference the urban green spaces contain floral species similar to natural or seminatural habitats, which confirms the importance of urban green patches as the most suitable ecological hotspots for the sustainability of native bees.

The year-long study of the diversity of bee flora that serve as potential foraging resources for bees in an urban habitat showed a strong positive relationship between floral diversity and that of native bee communities. The floral diversity dominated by ornamental plants nurtured the bees with continued supply of nutritional resources. With reducing natural habitat, the diverse bee friendly plant species in the urban green space can serve as the biological hotspot for the conservation of native bee diversity. Protection and restoration of existing green space and development of interconnected urban green network can further improve the gene flow and viability of bee species. The present data can guide policymakers and urban planners in developing sustainable green landscapes not only for the aesthetic appeal but also for their role in biodiversity conservation.

\section{Acknowledgements}

The first author would like to thank Dr. Anand Raju, Assistant Professor, Department of Botany, Jyoti Nivas College Autonomous, Bangalore for the invaluable help in identifying the plant species. The author also would like to acknowledge the help of Dr. Belwadi, Professor Emeritus, Gandhi Krishi Vigyana Kendra, Bangalore, for bee identification.

\section{Add-on Information}

Authors' contribution: V. R. Bhatta: Conceptualization, data collection, interpretation and manuscript preparation; A. N. Kumar: Supervision, data curation, review and editing.

Research content: The research content of manuscript is original and has not been published elsewhere.

\section{Ethical approval: NotApplicable}

Conflict of interest: The authors declare that there is no conflict of interest.

\section{Data from other sources: NotApplicable}

Consent to publish: All authors agree to publish the paper in Journal of Environmental Biology.

\section{References}

Aguirre-Gutiérrez, J., H.M. Serna-Chavez, A.R. Villalobos-Arambula, J.A. Perez de la Rosa and N. Raes: Similar but not equivalent: Ecological niche comparison across closely-related Mexican white pines. Divers. Distrib., 21, 245-257 (2015). 
Balachandran, C., M.D.S. Chandran and T.V. Ramachandra: Keystone food resources for honeybees in South India west coast during monsoon. Curr. Sci., 106, 1379-1386 (2014).

Baldock, K.C., M.A. Goddard, D.M. Hicks, W.E. Kunin, N. Mitschunas, L.M. Osgathorpe, S.G. Potts, K.M. Robertson, A.V. Scott, G.N. Stone and I.P. Vaughan: Where is the UK's pollinator biodiversity? The importance of urban areas for flower-visiting insects. P. Roy Soc. B-Biol. Sci., 282, 20142849 (2015).

Bates, A.J., J.P. Sadler, A.J. Fairbrass, S.J. Falk, J.D. Hale and T.J. Matthews: Changing bee and hoverfly pollinator assemblages along an urban-rural gradient. PLoS ONE, 6, e23459 (2011).

Biesmeijer, J.C., S.P.M. Roberts, M. Reemer, R. Ohlemuller, M. Edwards, T. Peeters, A.P. Schaffers, S.G. Potts, R. Kleukers, C.D. Thomas., J. Settele and W.E. Kunin: Parallel declines in pollinators and insect-pollinated plants in Britain and the Netherlands. Science, 313, 351-354 (2006).

Bista, S. and G.P. Shivakoti: Honeybee Flora at Kabre, Dolakha District. J. Nep. Agric. Res., 4, 18-25 (2001).

Bhatta, V.R. and A.N. Kumar: Native bee diversity and abundance in an urban green space in Bengaluru, India. J. Environ. Biol., 41, 1536$1541(2020)$

Carvell, C., D.B. Roy, S.M. Smart, R.F. Pywell, C.D. Preston and D. Goulson: Declines in forage availability for bumblebees at a national scale. Biol. Conserv., 132, 481-489 (2006).

Chalcoff, V.R., G. Gleiser, C. Ezcurra and M.AAizen: Pollinator type and secondarily climate are related to nectar sugar composition across the angiosperms. Evol. Ecol., 31, 585-602 (2017).

Daniels, B., J. Jedamski, R. Ottermanns and M. Ross-Nickoll: A "plan bee" for cities: Pollinator diversity and plant-pollinator interactions in urban green spaces. PLoS ONE, 15, e0235492 (2020).

Ebeling, A., A.M. Klein, J. Schumacher, W.W. Weisser and T. Tscharntke: How does plant richness affect pollinator richness and temporal stability of flower visits? Oikos, 117, 1808-15(2008).

Filipiak, M.A.: Better understanding of bee nutritional ecology is needed to optimize conservation strategies for wild bees-the application of ecological stoichiometry. Insects, 9, 85 (2018).

Frankie, G.W., R.W. Thorp, M. Schindler, J. Hernandez, B. Ertter and M. Rizzardi: Ecological patterns of bees and their host ornamental flowers in two Northern California cities. J. Kansas Entomol. Soci., 78, 227-246 (2005).

Fründ, J., K.E. Linsenmair and N. Blüthgen: Pollinator diversity and specialization in relation to flower diversity. Oikos, 119, 1581-1590 (2010).

Gallai, N., J.M. Salles, J. Settele and B.E. Vaissière: Economic valuation of the vulnerability of world agriculture confronted with pollinator decline. Ecol. Econ., 68, 810-821 (2009).

Hall, D.M., G.R. Camilo, R.K. Tonietto, J. Ollerton, K. Ahrné, M. Arduser and $D$. Goulson: The city as a refuge for insect pollinators. Conserv. Biol., 31, 24-29 (2017).

Hemalatha, D., J. Jayaraj, M. Murugan, T.N. Balamohan, N. Senthil, C. Chinniah and K. Suresh: Floral diversity for foraging of the Asiatic honey bee, Apis ceranaindica (Hymenoptera: Apidae) in Madurai District of Tamil Nadu, India. Int. J. Curr. Microbiol. App. Sci., 7, 3452-3456 (2018).

Hinners, S.J. and M.K. Hjelmroos-Koski: Receptiveness of foraging wild bees to exotic landscape elements. Am. Midland. Nat., 162, 253-265 (2009).

Hosamani, V., K.N. Kattimani and R. Nidagundi: Diversity of necteriferous and polleniferous bee flora and floral calendar of honey bees in dryland regions of Koppal District. J. Pharmacogn. Phytochem., SP3, 362-366 (2018).
Keller, I., P. Fluri and A. Imdorf: Pollen nutrition and colony development in honey bees: Part 1. Bee World, 86, 3-10 (2005).

Kerr, J.T., A. Pindar, P. Galpern, L. Packer, S.G. Potts, S.M. Roberts, P. Rasmont, O. Schweiger, S.R. Colla, L.L. Richardson and D.L. Wagner: Climate change impacts on bumblebees converge across continents. Science, 349, 177-180 (2015).

Klein, A.M., B.E. Vaissiere, J.H. Cane, I. Steffan-Dewenter, S.A. Cunningham, C. Kremen and T. Tscharntke: Importance of pollinators in changing landscapes for world crops. P. Roy. Soc. BBiol. Sci., 274, 303-313 (2007).

Mahale, M.B.: Potential of weeds/wild plants as bee flora with relation to agriculture and forestry. Int. J. ResAnal. Rev., 6, 664-670 (2019)

Matteson, K.C., J.S. Ascher and G.A. Langellotto: Bee richness and abundance in New York City urban gardens. Ann. Entomol. Soc. AM., 101, 140-50 (2008).

Pande, R. and G.I. Ramkrushna: Diversification of Honey bees' flora and bee flora calendar for Nagpur and Wardha districts of Maharashtra, India. J. Entomol. Zool. Stud., 6, 3102-3110 (2018).

Pardee, G.L. and S.M. Philpott: Native plants are the bee 's knees: Local and landscape predictors of bee richness and abundance in backyard gardens. Urban Ecosyst., 17,641-659 (2014).

Petanidou, T., A.S. Kallimanis, S.P. Sgardelis, A.D. Mazaris, J.D. Pantis and N.M. Waser: Variable flowering phenology and pollinator use in a community suggest future phenological mismatch. Acta. Oecol., 59, 104-11 (2014).

Potts, S.G., B. Vulliamy, A. Dafni, G. Ne'eman and P. Willmer: Linking bees and flowers: How do floral communities structure pollinator communities? Ecology, 84, 2628-2642 (2003)

Potts, S.G., V. Imperatriz-Fonseca, H.T. Ngo, M.A. Aizen, J.C. Biesmeijer, T.D. Breeze and A.J. Vanbergen: Safeguarding pollinators and their values to human well-being. Nature, 540, 220229 (2016).

Riedinger, V., M. Renner, M. Rundlof, I. Steffan-Dewenter and A. Holzschuh: Early mass-flowering crops mitigate pollinator dilution in late-flowering crops. Landsc. Ecol., 29, 425-435 (2014).

Rosenzweig, M.L.: Reconciliation ecology and the future of species diversity. Oryx, 37,194-205 (2003).

Roulston, T.H. and K. Goodell: The role of resources and risks in regulating wild bee populations. Annu. Rev. Entomol., 56, 293 $312(2011)$

Roultson, T.H., J.H. Cane and S.L. Buchmann: What governs protein content of pollen: Pollinator preferences, pollen pistil interactions, or phenology? Ecol. Monogr., 7, 617-643 (2000).

Stoate, C., A. Báldi, P. Beja, N.D. Boatman, I. Herzon, A. Van Doorn and C. Ramwell: Ecological impacts of early $21^{\text {st }}$ century agricultural change in Europe-a review. J. Environ. Manage., 91, 22-46 (2009).

Threlfall, C.G., K. Walker, N.S. Williams, A.K. Hahs, L. Mata, N. Stork and S.J. Livesley: The conservation value of urban green space habitats for Australian native bee communities. Biol. Conserv. 187, 240-248 (2015).

Tilman, D., J. Fargione, B. Wolff, C. D'Antonio, A. Dobson, R. Howarth, D. Schindler, W.H. Schlesinger, D. Simberloff and D. Swackhamer: Forecasting agriculturally driven global environmental change. Science, 292, 281-284 (2001).

Todd, K.J., M.M. Gardiner and E.D. Lindquist: Mass flowering crops as a conservation resource for wild pollinators (Hymenoptera: Apoidea). J. Kansas. Entomol. Soc., 89, 158-167 (2016).

Vidhya, A., K. Suresh, C. Chinni, V. Krishnamoorthy and M. Shanthi: Floral diversity and foraging behaviour of little/dwarf honey bee Apis florea f. in horticultural ecosystem, Madurai District, Tamil Nadu, Indian. J. Entomol., 81, 775-778 (2019).

Waykar, B., R.K. Baviskar and T.B. Nikam: Diversity of nectariferous and 
polleniferous bee flora at Anjaneri and Dugarwadi hills of Western Ghats of Nasik district (M.S.) India. J. Entomol. Zool. Stud., 2, 244249 (2014).

Waykar, B. and R.K. Baviskar: Diversity of bee foraging flora and floral calendar of Paithan taluka of Aurangabad district (Maharashtra), India. J. Appl. Hortic., 17, 155-159 (2015).

Weiner, C.N., M. Werner, K.E. Linsenmair and N. Blüthgen: Land-use impacts on plant-pollinator networks: Interaction strength and specialization predict pollinator declines. Ecology, 95, 466-474 (2014).

Westphal, C., R. Bommarco, G. Carré, E. Lamborn, N. Morison, T.
Petanidou, S.G. Potts, S.P.M. Roberts, H. Szentgyörgyi, T. Tscheulin, B.E. Vaissière, M. Woyciechowski, J.C. Biesmeijer, W.E. Kunin, J. Settele and I. Steffan-Dewenter: Measuring bee biodiversity in different European habitats and biogeographical regions. Ecol. Monogr., 78, 653-671 (2008)

Woodard, S.H. and S. Jha: Wild bee nutritional ecology: predicting pollinator population dynamics, movement, and services from floral resources. Curr. Opin. Insect. Sci., 21, 83-90 (2017).

Wubie, A.J., A. Bezabeh and K. Kebede: Floral phenology and pollen potential of honey bee plants in North-East dry land areas of Amhara region, Ethiopia, IOSR J. Agric. Vet. Sci., 7, 36-49 (2014). 